\title{
The Oxidant and Antioxidant Status in $\beta$-Thalassemia Major Patients
}

\author{
ALIAA A.F. IBRAHIM, M.Sc.*; TAMER A. EL-BEDEWY, M.D.*; EBAA H. EL-SHEIKH, M.D.* and \\ AMAL HELMY ABD EL-HAMEED, M.D.** \\ The Departments of Internal Medicine * and Clinical Pathology**, Faculty of Medicine, Tanta University
}

\begin{abstract}
Background: Thalassemia is associated with anemia and lifelong blood transfusion that lead to oxidant-antioxidant disturbance due to massive iron deposits with generation of labile iron in the red blood cells, which promotes the formation of Reactive Oxygen Species (ROS) with cumulative cell damage.
\end{abstract}

Aim of the Work: Evaluation of Ischemia ModifiEd Albumin (IMA) as a marker of oxidative stress and Superoxide Dismutase (SOD) as a marker of antioxidant status in patients with $\beta$-Thalassemia Major $(\beta-\mathrm{TM})$.

Subjects and Methods: Forty patients with $\beta$-TM were divided into 2 groups well chelated (group 1) and poorly chelated (group 2). Twenty healthy participants of matched age and sex were taken as controls (group 3). All patients and controls were subjected to complete history taking, clinical examination. Serum ferritin, IMA and SOD were measured.

Results: There were significant higher levels of IMA in thalassemia patients than controls ( $p$-value $<0.001^{*}$ ). IMA correlated significantly positive with serum ferritin $(r=0.339$, $p$-value $0.032 *)$. There were significant lower levels of SOD in thalassemia patients than controls $\left(p\right.$-value $\left.<0.001^{*}\right)$. SOD correlated significantly negative with serum ferritin $(r=-0.718$, $p$-value $<0.001 *)$.

Conclusion: IMA as a new marker of oxidative stress increased in $\beta$-TM patients and SOD as a marker of antioxidant status decreased in $\beta$-TM patients.

Key Words: $\beta$-thalassemia major-Oxidant-Antioxidant Ischemia Modified Albumin (IMA) - Superoxide Dismutase (SOD).

\section{Introduction}

$\beta$-THALASSEMIA syndromes are the most common inherited hemoglobinopathies in the world caused by an autosomal recessive genetic deficiency in the $\beta$-globin chain synthesis leading to accumulation of unpaired $\beta$-globin chains [1].

Correspondence to: Dr. Aliaa A.F. Ibrahim, The Department of Internal Medicine, Faculty of Medicine, Tanta University
$\beta$-Thalassemia Major ( $\beta$-TM) is the most severe form and is typically diagnosed with profound anemia during infancy, requiring long-term transfusion and iron chelation therapy for survival [2] Patient with thalassemia develops several complications including cardiac, endocrinal, and hepatic dysfunctions. Several factors are responsible for these abnormalities including hemolysis and excess iron deposition [3]

The status of iron overload and iron-induced oxidative stress has been repeatedly investigated in patients with $\beta$-thalassemia major [4]. Many studies reported increased serum ferritin levels, blood levels of the redox active fractions of NonTransferrin Bound Iron (NTBI) and Labile Plasma Iron (LPI) in patients with $\beta$-thalassemia [5] . It has also been demonstrated that such patients experience decreased antioxidant capacity [6] .

Reactive Oxygen Species (ROS) resulting from conditions such as ischemia, hypoxia and free iron can decrease the ability of the N-terminus of serum albumin to bind with transition metals such as cobalt, copper and nickel [7]. Human serum albumin with a decreased binding capacity as a result of ischemic events and oxidative stress is referred to as Ischemia ModifiEd Albumin (IMA) [8]

IMA is currently used as an early marker for myocardial ischemia [9]. However, recent studies have reported increased levels of IMA in conditions other than ischemic heart diseases including diabetes mellitus and hyperlipidemia [10].

Endogenous antioxidants, like Superoxide Dismutase (SOD) is the first barriers to the change of the internal environment influenced by the increase of free radicals and abundant stress, creating superactive oxygen. However, much of the data from thalassemic patients state that SOD level can vary 
from a low level, no different from healthy individuals, up to a high level [11].

\section{Subjects and Methods}

This cross-sectional study was carried out on 40 patients with beta thalassemia major ( (3-TM); they were randomly selected from in and outpatients of the Hematology Unit, Internal Medicine Department, Faculty of Medicine, Tanta University in the period from July 2016 to December 2016. Twenty healthy participants of matched age and sex were taken as controls. All participant provided informed written consent and the study was approved by Tanta Faculty of Medicine Ethical Committee.

\section{The subjects were divided into 3 groups:}

Group 1: 20 well chelated (3-TM patients (with mean serum ferritin $<2500 \mathrm{ng} / \mathrm{ml}$ ).

Group 2: 20 poorly chelated (3-TM patients (with mean serum ferritin $>2500 \mathrm{ng} / \mathrm{ml}$ ).

Group 3: 20 age-matched and sex-matched healthy participants were included in the study as controls.

\section{Exclusion criteria:}

Patients with other hemoglobinopathies, other hemolytic anemia, liver cell failure, hypothyroidism, hyperthyroidism, diabetes mellitus, acute inflammation, cardiac diseases.

All patients and controls will be subjected to full history taking including age, sex, disease duration, first time of blood transfusion, number of blood transfusions/year, history of splenectomy, postsplenectomy duration, and type and duration of chelation therapy. Complete clinical examination including weight, height. Laboratory investigations including Complete Blood Count (CBC), serum ferritin level, serum Ischemia Modified Albumin (IMA), serum Superoxide Dismutase level (SOD).

All samples were taken under complete aseptic measures, withdrawal of $5 \mathrm{ml}$ venous blood sample was done from both patients and controls, $1 \mathrm{ml}$ of which was placed on EDTA-vacationer for complete blood count, $3.5 \mathrm{ml}$ was centrifuged at room temperature 10-20 minutes at speed of 2000-3000 r.p.m for serum separation and was stored at -20 degrees for assay of serum ferritin and serum ischemia modified albumin. The remaining $0.5 \mathrm{ml}$ of blood was placed on EDTA for measurement of superoxide dismutase level. The sample was cen- trifuged for 10 minutes at 4000r.p.m, the plasma was aspirated off, erythrocytes were washed 4 times with $3 \mathrm{ml}$ of $0.9 \mathrm{NaCl}$ solution, then were centrifuged for 10 minutes at 4000r.p.m after each wash, then $2 \mathrm{ml}$ of cold redistilled water was added to the washed centrifuged erythrocytes and immediately was stored at -70 degrees. All samples were taken before transfusion.

\section{Statistical analysis:}

Statistical presentation and analysis of the present study was conducted, using the mean, standard deviation, Chi-square, Linear Correlation Coefficient and Analysis of variance [ANOVA] tests by SPSS (V17). Chi-square the hypothesis that the row and column variables are independent, without indicating strength or direction of the relationship. Pearson chi-square and likelihoodratio chi-square. Linear correlation coefficient was used for detection of correlation between two quantitative variables in one group. ANOVA test was used for comparison among different times in the same group in quantitative data. A $p$-value of less than 0.05 was considered statistically significant.

\section{Results}

Our study included 40 adult patients with (3TM (well chelated and poorly chelated) (group $1,2)$. Twenty healthy participants of matched age and sex were taken as controls (group 3). There were insignificant difference between all the studied groups as regard sex and age respectively ( $p$-value $=$ $0.419,0.909$ ) (Tables 1,2).

Our results showed significantly lower levels of Hemoglobin $(\mathrm{Hb})$ in (3-TM patients in comparison with controls (Table 3).

Our results showed significantly higher levels of serum ferritin in (3-TM patients in comparison with controls and higher level of serum ferritin in poorly chelated in comparison with well chelated patients. Table (4) and Fig. (1).

There were significantly higher levels of IMA in poorly chelated in comparison with well chelated patients. And, significantly higher levels of IMA in TM patients especially poorly chelated in comparison with controls. Table (5) and Fig. (2).

There were significantly lower levels of SOD in TM patients in comparison with controls. And, significantly higher levels of SOD in well chelated when compared with poorly chelated patients. Table (6) and Fig. (3). 
Table (7) and Fig. (4A,B): There were significantly negative correlation between IMA and SOD levels $(r=0.342, p$-value $=0.031 *)$.

There were significantly positive correlation between IMA and serum ferritin levels $(r=0.339$, $p$-value $=0.032 *$.

There were insignificant correlation between IMA and (age, $\mathrm{Hb}$ ) in thalassemia patients ( $p$-value $=0.367,0.916$ ) respectively.

Table (8) and Fig. (5): There were significantly negative correlation between SOD and serum ferritin levels $(r=-0.718, p$-value $<0.001 *)$.

There were insignificant correlation between SOD and (age, $\mathrm{Hb})(p$-value $=0.808,0.882)$ respectively.

Table (1): Comparison between all the studied groups as regard sex.

\begin{tabular}{|c|c|c|c|c|c|c|c|c|}
\hline \multirow{3}{*}{ Sex } & \multicolumn{8}{|c|}{ Groups } \\
\hline & \multirow{2}{*}{\multicolumn{2}{|c|}{ 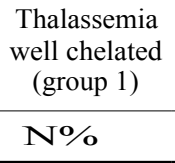 }} & \multicolumn{2}{|c|}{$\begin{array}{c}\text { Thalassemia } \\
\text { poorly chelated } \\
\left.\text { (group }^{2}\right)\end{array}$} & \multicolumn{2}{|c|}{$\begin{array}{l}\text { Controls } \\
\left(\text { group }^{3} \text { ) }\right.\end{array}$} & \multicolumn{2}{|c|}{$\begin{array}{l}\text { Chi- } \\
\text { square } \\
\text { test }\end{array}$} \\
\hline & & & $\mathrm{N}$ & $\%$ & $\mathrm{~N}^{\mathrm{c}}$ & $\%$ & $x^{2}$ & $p$-value \\
\hline Male & 10 & 50.0 & 9 & 45.0 & 13 & 65.00 & 1.741 & 0.419 \\
\hline Female & 10 & 50.0 & 11 & 55.0 & & 35.00 & & \\
\hline Total & 20 & 100.00 & 20 & 100.00 & 20 & 100.00 & & \\
\hline
\end{tabular}

Table (2): Comparison between all the studied groups as regard age.

\begin{tabular}{lcccc}
\hline \multirow{2}{*}{ Groups } & \multicolumn{2}{c}{ Age (years) } & \multicolumn{2}{c}{ ANOVA test } \\
\cline { 2 - 5 } & Range & Mean \pm SD & F & $p$-value \\
\hline - Thalassemia well \\
$\begin{array}{c}\text { chelated (group 1) } \\
\text { - Thalassemia poorly } \\
\text { chelated (group 2) }\end{array}$ & $18-36$ & $24.900 \pm 5.036$ & 0.096 & 0.909 \\
- Controls (group 3) & $19-38$ & $24.350 \pm 4.902$ & & \\
\hline
\end{tabular}

Table (3): Comparison between all the studied groups as regard Hemoglobin $(\mathrm{Hb})$ level.

\begin{tabular}{|c|c|c|c|c|}
\hline \multirow{2}{*}{ Groups } & \multicolumn{2}{|c|}{$\mathrm{Hb}(\mathrm{gm} / \mathrm{dl})$} & \multicolumn{2}{|c|}{ ANOVA test } \\
\hline & Range & Mean $\pm \mathrm{SD}$ & $\mathrm{F}$ & $p$-value \\
\hline $\begin{array}{l}\text { Thalassemia well } \\
\text { chelated (group 1) }\end{array}$ & $6.5-9$ & $7.830 \pm 0.712$ & 238.800 & $<0.001^{*}$ \\
\hline $\begin{array}{l}\text { - Thalassemia poorly } \\
\text { chelated (group 2) }\end{array}$ & $6.4-9.5$ & $7.700 \pm 0.974$ & & \\
\hline • Controls (group 3) & $11.4-12.8$ & $12.17 \pm 0.408$ & & \\
\hline \multicolumn{5}{|c|}{ TUKEY'S test } \\
\hline Group $1 \& 2$ & \multicolumn{2}{|c|}{ Group $1 \& 3$} & \multicolumn{2}{|c|}{ Group $2 \& 3$} \\
\hline 0.842 & \multicolumn{2}{|c|}{$<0.001 *$} & \multicolumn{2}{|c|}{$<0.001^{*}$} \\
\hline
\end{tabular}

Table (4): Comparison between all the studied groups as regard serum ferritin level.

\begin{tabular}{|c|c|c|c|c|}
\hline \multirow{2}{*}{ Groups } & \multicolumn{2}{|c|}{ S. ferritin (ng/ml) } & \multicolumn{2}{|c|}{ ANOVA test } \\
\hline & Range & Mean \pm SD & $\mathrm{F}$ & $p$-value \\
\hline $\begin{array}{l}\text { - Thalassemia } \\
\text { well chelated } \\
\text { (group 1) }\end{array}$ & $145-2217$ & $1247.900 \pm 608.709$ & 9 224.008 & $<0.001^{*}$ \\
\hline $\begin{array}{l}\text { Thalassemia } \\
\text { poorly chelated }\end{array}$ & $2500-4000$ & $3031.850 \pm 452.926$ & & \\
\hline $\begin{array}{l}\left.\operatorname{\text {group}}^{2}\right) \\
\quad \text { Controls } \\
(\text { group } 3)\end{array}$ & $30-280$ & $115.600 \pm 57.348$ & & \\
\hline \multicolumn{5}{|c|}{ TUKEY'S test } \\
\hline \multicolumn{2}{|l|}{ Group $1 \& 2$} & roup $1 \& 3$ & \multicolumn{2}{|c|}{ Group $2 \& 3$} \\
\hline$<0.001^{*}$ & & $<0.001^{*}$ & $<0.001^{\prime}$ & \\
\hline
\end{tabular}

Table (5): Comparison between all the studied groups as regard Ischemia Modified Albumin (IMA) level.

\begin{tabular}{|c|c|c|c|c|}
\hline \multirow{2}{*}{ Groups } & \multicolumn{2}{|c|}{ IMA (ng/ml) } & \multicolumn{2}{|c|}{ ANOVA test } \\
\hline & Range & Mean \pm SD & $\mathrm{F}$ & $p$-value \\
\hline $\begin{array}{l}\text { - Thalassemia well } \\
\text { chelated (group 1) }\end{array}$ & $35-111$ & $68.600 \pm 23.473$ & 11.341 & $<0.001 *$ \\
\hline $\begin{array}{l}\text { - Thalassemia poorly } \\
\text { chelated (group } 2 \text { ) }\end{array}$ & $46-368$ & $141.250 \pm 98.766$ & & \\
\hline - Controls (group 3) & $57-68$ & $61.450 \pm 2.819$ & & \\
\hline \multicolumn{5}{|c|}{ TUKEY'S test } \\
\hline Group $1 \& 2$ & \multicolumn{2}{|c|}{ Group $1 \& 3$} & \multicolumn{2}{|c|}{ Group $2 \& 3$} \\
\hline$<0.001 *$ & \multicolumn{2}{|r|}{0.921} & \multicolumn{2}{|c|}{$<0.001 *$} \\
\hline
\end{tabular}

Table (6): Comparison between all the studied groups as regard Superoxide Dismutase (SOD) level.

\begin{tabular}{|c|c|c|c|c|}
\hline \multirow{2}{*}{ Groups } & \multicolumn{2}{|c|}{$\mathrm{SOD}(\mathrm{U} / \mathrm{ml})$} & \multicolumn{2}{|c|}{ ANOVA test } \\
\hline & Range & Mean $\pm \mathrm{SD}$ & $\mathrm{F}$ & $p$-value \\
\hline $\begin{array}{l}\text { - Thalassemia well } \\
\text { chelated (group 1) }\end{array}$ & $86-153$ & $108.200 \pm 20.320$ & 227.259 & $<0.001^{*}$ \\
\hline $\begin{array}{l}\text { - Thalassemia poorly } \\
\text { chelated (group 2) }\end{array}$ & $35-70$ & $51.950 \pm 11.537$ & & \\
\hline - Controls (group 3) & $164-260$ & $201.400 \pm 30.956$ & & \\
\hline \multicolumn{5}{|c|}{ TUKEY'S test } \\
\hline Group $1 \& 2$ & \multicolumn{2}{|c|}{ Group $1 \& 3$} & \multicolumn{2}{|c|}{ Group $2 \& 3$} \\
\hline$<0.001 *$ & \multicolumn{2}{|c|}{$<0.001 *$} & \multicolumn{2}{|c|}{$<0.001 *$} \\
\hline
\end{tabular}

Table (7): Correlation between IMA and (SOD, age, $\mathrm{Hb}$ and serum ferritin) in thalassemia patients.

\begin{tabular}{lcc}
\hline \multicolumn{3}{c}{ Correlations } \\
\cline { 2 - 3 } Thalassemia & \multicolumn{2}{c}{ IMA $(\mathrm{ng} / \mathrm{ml})$} \\
\cline { 2 - 3 } & \multicolumn{2}{c}{$p$-value } \\
\hline SOD $(\mathrm{U} / \mathrm{ml})$ & 0.342 & $0.031^{*}$ \\
Age $($ years $)$ & -0.017 & 0.367 \\
Hb (gm/dl) & 0.339 & 0.916 \\
S. ferritin $(\mathrm{ng} / \mathrm{ml})$ & & $0.032^{*}$ \\
\hline
\end{tabular}


Table (8): Correlation between SOD and (age, $\mathrm{Hb}$ and serum ferritin) in thalassemia patients.

\begin{tabular}{lcc}
\hline \multicolumn{3}{c}{ Correlations } \\
\cline { 2 - 3 } Thalassemia & \multicolumn{2}{c}{ SOD (U/ml) } \\
\cline { 2 - 3 } & $r$ & $p$-value \\
\hline Age (years) & 0.040 & 0.808 \\
Hb (gm/dl) & -0.024 & 0.882 \\
S.ferritin (ng/ml) & -0.718 & $<0.001^{*}$ \\
\hline
\end{tabular}

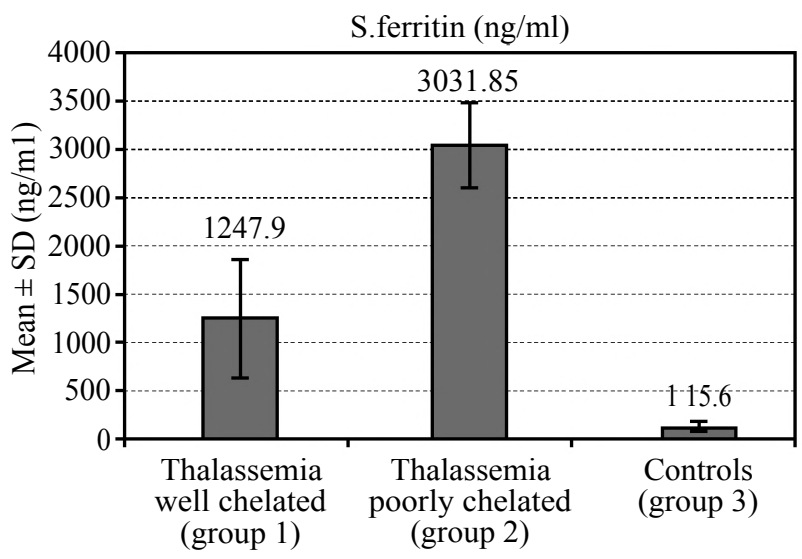

Fig. (1): Comparison between all the studied groups as regard serum ferritin level.

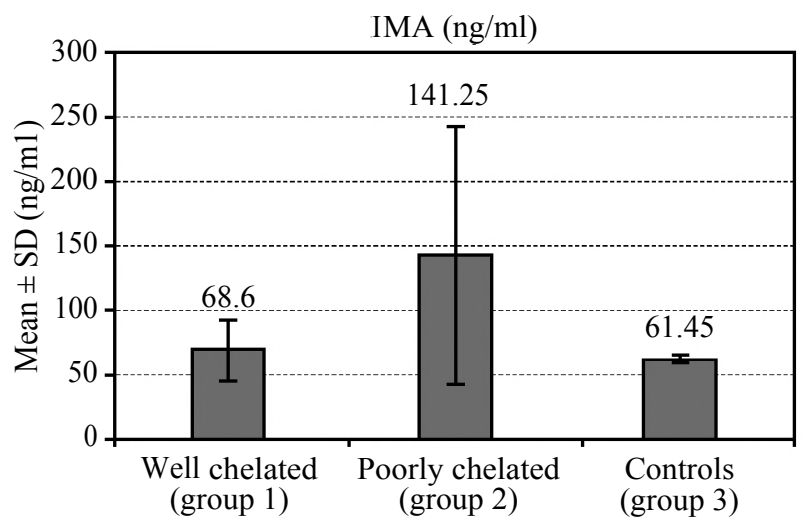

Fig. (2): Comparison between all the studied groups as regard ischemia modified albumin (IMA) level.

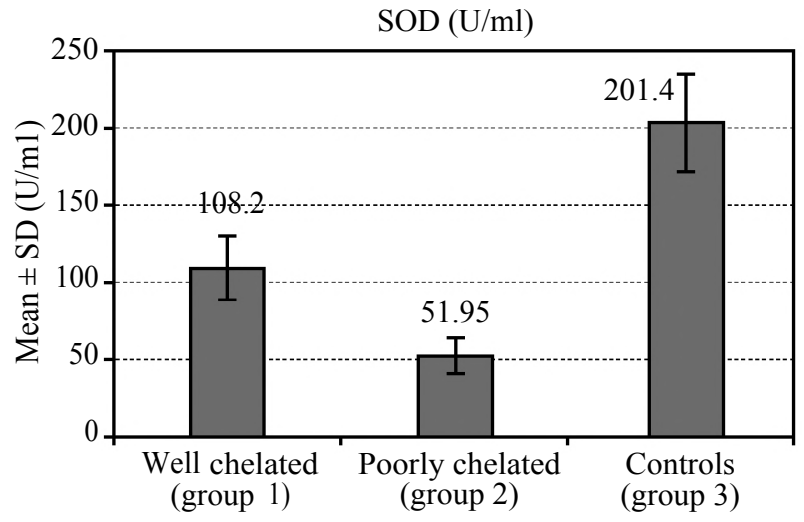

Fig. (3): Comparison between all the studied groups as regard SOD level.

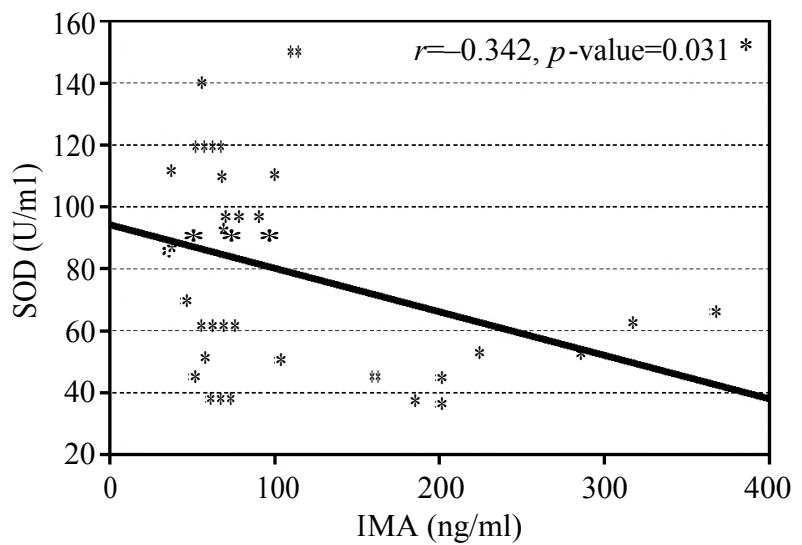

Fi. (4A): Correlation between IMA level and SOD level in thalassemia patients.

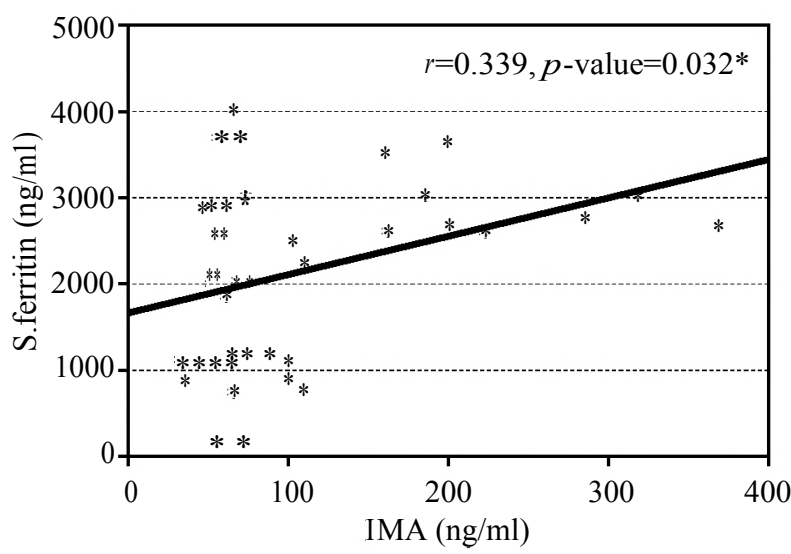

Fig. (4B): Correlation between IMA level and serum ferritin level in thalassemia patients.

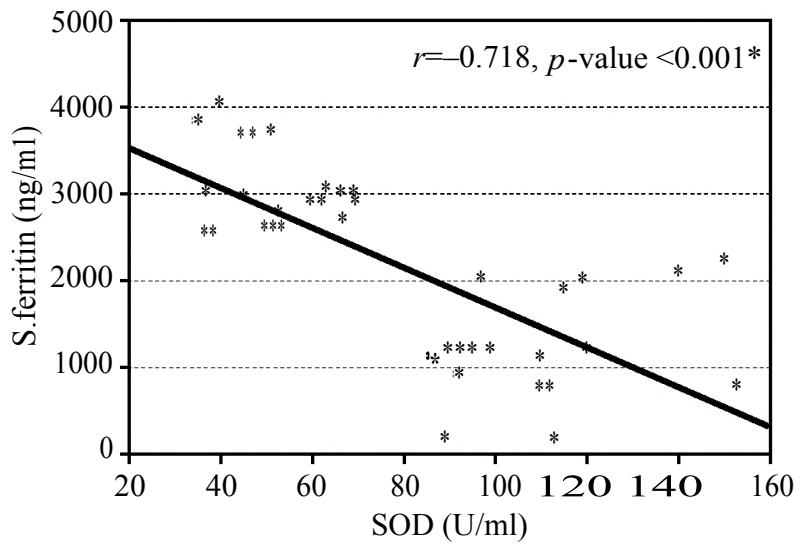

Fig. (5): Correlation between SOD level and serum ferritin level in thalassemia patients.

\section{Discussion}

Patients with thalassemia major are transfusiondependent. Iron overload causes most of the mortality and morbidity and excess iron is deposited in major organs resulting in organ damage [12] Effective and convenient iron chelation therapy remains one of the main targets of clinical management of thalassemia major [13] . 
High serum ferritin is a predictable consequence of continuous blood transfusion in thalassemia patients, it remains the most common indicator of iron overload in thalassemia patients [14]. In agreement with these observations, high levels of serum ferritin noted in our patients are strongly suggestive of a state of iron overload. As a result of iron overload, redox active fractions such as NonTrasferrin-Bound Iron (NTBI) and Labile Plasma Iron (LPI) are expected to increase in circulation $[\mathbf{5 , 1 2}]$. These fractions can catalyze the production of ROS contributing to significant tissue injury. Under such conditions, it is very possible that such redox active forms of iron could contribute to the formation of IMA in thalassemia patient; a finding that has been noted by this study.

In our study, IMA was significantly higher in thalassemia patients compared with the control ( $p$ $<0.001 *)$. In agreement with our results, Awadallah et al., [15] . They attributed their finding to the increased level of IMA in thalassemia patients that are likely to be a result of iron-induced oxidative stress and hence its potential significance as a new marker of oxidative stress in such patients. In addition, Sbarouni et al., [16] postulated that overproduction of Reactive Oxygen Species (ROS) resulting from conditions related to ischemia, hypoxia, acidosis, free radicals, and free iron plays a major role in the formation of IMA. Generation of ROS can transiently modify the N-terminal region of albumin and produce an increase in IMA levels [17]

In our study, we noticed a significant positive correlation between serum ferritin and IMA levels $(r=0.339, p$-value $=0.032 *)$. This is in accordance with the study by Awadallah et al., [15]. When iron overload exceeds the storage capacity of the cell, free iron start to deposit in the organs and that in turn leads to overproduction of ROS that plays a major role in the formation of IMA $[\mathbf{1 6 , 1 8}]$.

Our study proved that IMA level was significantly higher in poorly chelated thalassemia patients with serum ferritin $\geq 2500 \mathrm{ng} / \mathrm{ml}$ when compared with well chelated thalassemia patients with serum ferritin $<2500 \mathrm{ng} / \mathrm{ml}(141.250 \pm 98.766$ vs $68.600 \pm$ $23.473, p$-value $<0.001 *)$. Similar to our results, Akrawinthawong et al., [19] stated that Deferiprone (DFP) therapy alone improved iron overload and oxidative stress [19]. This can be attributed to the fact that DFP chelates the excess of iron, reducing the circulating and intracellular free iron that lead to decreased formation of ROS [20]

SOD is an intracellular enzyme that is responsible for changes in the oxidant-antioxidant balance in cells. Enzyme function is to catalyze modifying ion free radicals, especially $\mathrm{O}_{2}$ - into $\mathrm{H}_{2} \mathrm{O}$ [21]. In subjects with thalassemia, enormous free radicals built up due to the state of iron overload (resulting from transfusions and ineffective erythropoiesis). Iron $(\mathrm{Fe})$ is able to accelerate the change of molecular oxygen into reactive oxygen radicals, superoxide, and hydroxyl groups through the Fenton reaction $[22,23]$.

Our study proved that SOD level was significantly lower in thalassemia patients when compared with control ( $p$-value $<0.001 *)$.

Similar to our results, Patne et al., [24] also present data showing that the levels of erythrocyte antioxidant enzymes, especially SOD activity, decreased significantly in patients who were transfusion-dependent.

However, different results were shown by other research centers. Simsek et al., [25] found that the level of SOD in thalassemia patients were higher than the healthy control. Other publications mention that SOD did not show significant differences between healthy controls and thalassemia subjects [26].

Increased levels of antioxidants, including SOD, occur in various circumstances: Including an acute inflammatory phase, a state of trauma, and upon exposure to increased levels of pro-oxidants. The increase was associated with a compensatory mechanism to break down free radicals had been caused by oxidative stress and lipid peroxidation $[27,28]$ This is supported by other publications, which state that chronic stress in diabetes mellitus, metabolic syndrome, chronic liver disease, SLE, and rheumatoid arthritis affect the decrease in antioxidant enzyme capacity [29-31]

In our study, there was significant negative correlation between SOD and serum ferritin. SOD decreased in poorly chelated patients with s.ferritin $\geq 2500 \mathrm{ng} / \mathrm{ml}$ when compared with well chelated with s.ferritin $<2500 \mathrm{ng} / \mathrm{ml}$ ( $r=-0.718, p$-value $<0.001 *)$.

Research in Jakarta said that the decrease of antioxidant enzymes in patients related to nonchelating subjects, while administration of chelation therapy on a regular basis, could increase the capacity of the enzymes SOD [31-33].

In many cases with impaired oxidant-antioxidant mechanisms, administrating an iron chelator will improve the prognosis of various disorders, 
including neurodegenerative disease, cardiovascular impairment and iron overload [34-37].

\section{Conclusion:}

From this study, we concluded that Ischemia ModifiEd Albumin (IMA) as a new marker of oxidative stress increased in patients with (3thalassemia major especially poorly chelated. Superoxide Dismutase (SOD) is a marker of antioxidant status which decreased in (3-thalassemia major patients especially poorly chelated.

\section{Recommendations:}

Further studies to investigate oxidant and antioxidant status in thalassemia on large scale of patients for long duration and with more advanced methods, to determine the benefit of administering the selective antioxidant therapy, a well-balanced diet on oxidative injury in thalassemia patients and use of chelating agents to reduce high ferritin level.

\section{Acknowledgements:}

We would like to thank all participants who helped during this study.

\section{Conflict of interest:}

None declared.

\section{References}

1- YESILIPEK M.A.: Successful hematopoietic SCT from non-identical twins to two sisters with (3-thalassemia major by using preimplantation genetic diagnosis and HLA typing. Bone Marrow Transplantation, 46: 1581-2, 2011.

2- SMITH G.S., ALPENDURADA F., CARPENTER J.P., et al.: Effect of deferiprone or deferoxamine on right ventricular function in thalassemia major patients with myocardial iron overloadJournal of Cardiovascular Magnetic Resonance, 13: 3, 2011.

3- BORGNA-PIGNATTI C. and GALANELLO R.: Thalassemias and related disorders: Quantitative disorders of hemoglobin synthesis. In: John P.G., John F., John N.L.H., editors. Wintrobe's clinical hematology. 11 th ed. Philadelphia: Lippincott Williams \& Wilkins, 42: 131965, 2004.

4- KOREN A., FINK D., ADMONI O., et al.: Non-transferrin bound labile plasma iron and iron overload in sickle cell disease: A comparative study between sickle cell disease and (3-thalassemic patients. Eur. J. Haematol., 84: 72-8, 2010.

5- CABANTCHIK Z.I., BREUER W., ZANNINELLI G., et al.: Labile iron in cells and body fluids: Physiology, pathology, and pharmacology. Frontiers in Pharmacology, 5: 45,2014

6- BAZVAND F., SHAMS S., BORJI ESFAHANI, et al.: Total Antioxidant Status in Patients with Major (3Thalassemia. Iranian Journal of Pediatrics, 21 (2): 15965, 2011.
7- MEHMETOGLU I. KURBAN S. YERLIKAYA F.H., et al.: Obesity Is an Independent Determinant of IschemiaModified Albumin. Obes. Facts., 5: 700-9, 2012.

8- BAR-OR D., LAU E. and WINKLER J.V.: A novel assay for cobalt-albumin binding and its potential as a marker for myocardial ischemia-a preliminary report. J. Emerg. Med., 19: 311-5, 2000.

9- GURUMURTHY P., BORRA S.K., YERUVA R.K.R., et al.: Estimation of Ischemia Modified Albumin (IMA) Levels in Patients with Acute Coronary Syndrome. Ind. J. Clin. Biochem., 329: 367, 2014.

10- MARTA M.M., JOAO B.T., RAFAEL N., et al.: Association between ischemia-modified albumin, lipids and inflammation biomarkers in patients with hypercholesterolemia. Clin. Biochem., 42: 666-71, 2009.

11- KATTAMIS C., LAZAROPOULOU C., DELAPORTA P., et al.: Disturbances of biomarkers of iron and oxidantantioxidant homeostasis in patients with beta-thalassemia intermedia. Pediatr. Endocrinol. Rev., 8: 256-62, 2011.

12- CAZZOLA M., DELLA PORTA M. and MALCOVATI L.: Clinical relevance of anemia and transfusion iron overload in myelodysplastic syndromes. Hematology Am. Soc. Hematol. Educ. Program., 2008 (1): 166-75, 2008.

13- PILO F., Di TUCCI A.A., DESSÌ L., et al.: Management of transfusional chronic iron overload: Focus on deferasirox. Clinical Medicine: Therapeutics, 1: 735-45, 2009.

14- RITESH N. SHARMA and S.S. PANCHOLI: Oral Iron Chelators: A New Avenue for the Management of Thalassemia Major. Journal of Current Pharmaceutical Research, 01: 1-7, 2010.

15- AWADALLAH S.M., ATOUM M.F., NIMER N.A., et al.: Ischemia modified albumin: An oxidative stress marker in (3-thalassemia major. Clinica. Chimica. Acta., 413: 907-10, 2010.

16- SBAROUNI E., GEORGIADOU P. and VOUDRIS V.: Ischemia modified albumin changes-review and clinical implications. Clin. Chem. Lab. Med., 49: 177-84, 2011.

17- KANKO M., YAVUZ S., DUMAN C., et al.: Ischemiamodified albumin use as a prognostic factor in coronary bypass surgery. Journal of Cardiothoracic Surgery, 7: 3, 2012.

18- ABDUL-RAZZAK A., AL-SHIMMARY L. and HEMID A.: The effect of deferasirox on the oxidative stress and inflammation in iron overloaded beta-thalassemic patients. Med. J. Babylon., 10: 257-64, 2013.

19- AKRAWINTHAWONG K., CHAOWALIT N., CHATUPARISUTH T. and SIRITANARATKUL N.: Effectiveness of deferiprone in transfusion-independent beta-thalassemia/HbE patients. Hematol., 16: 113-22, 2011.

20- VALLE GOTTLIEB M.G., Da CRUZ I.B., DUARTE M.M., et al.: Associations among metabolic syndrome, ischemia, inflammatory, oxidatives, andlipidsbiomarkers. J. Clin. Endocrinol. Metab., 95: 586-91, 2010.

21- FUKAI T. and USHIO-FUKAI M.: Superoxide dismutases: Role in redox signaling, vascular function, and diseases. Antioxid. Redox. Signal., 15: 1583-606, 2011.

22- RIFKIND J.M., MOHANTY J.G. and NAGABABU E.: The pathophysiology of extracellular hemoglobin associ- 
ated with enhanced oxidative reactions. Front. Physiol., 5: 500, 2015.

23- SHAZIA Q., MOHAMMAD Z.H., RAHMAN T., et al.: Correlation of oxidative stress with serum trace element levels and antioxidant enzyme status in beta thalassemia major patients: A review of literature. Anemia; 2012: 270923, 2012.

24- PATNE A.B., HISALKAR P.J., GAIKWAD S.B., et al.: Alterations in antioxidant enzyme status with lipid peroxidation in thalassemia major patients. Int. J. Pharm. Life Sci.; 3: 2003-6, 2012.

25- SIMSEK F., ÖZTÜRK G., KEMAHLı S., et al.: Oxidant and antioxidant status in beta thalassemia major patients. Ankara Üniversitesi Tıp Fakültesi Mecmuas1; 8: 34-58, 2005.

26- GHONE R.A., KUMBAR K.M., SURYAKAR A.N., et al.: Oxidative stress and disturbance in antioxidant balance in beta thalassemia major. Indian J. Clin. Biochem.; 23: $337-40,2008$

27- LÜ J.M., LIN P.H., YAO Q., et al.: Chemical and molecular mechanisms of antioxidants: Experimental approaches and model systems. J. Cell. Mol. Med.; 14: 840-60, 2010.

28- WILLCOX J.K., ASH S.L. and CATIGNANI G.L.: Antioxidants and prevention of chronic disease. Crit. Rev. Food. Sci. Nutr.; 44: 275-95, 2004.

29- RAMAKRISHNA V. and JAILKHANI R.: Evaluation of oxidative stress in Insulin Dependent Diabetes Mellitus (IDDM) patients. Diagn. Pathol.; 2: 22-33, 2007.

30- CARDIN R., PICIOCCHI M., BORTOLAMI M., et al.: Oxidative damage in the progression of chronic liver disease to hepatocellular carcinoma: An intricate pathway. World J. Gastroenterol.; 20: 3078-86, 2014.

31- WASEEM F., KHEMOMAL K.A. and SAJID R.: Antioxidant status in beta thalassemia major: A single-center study. Indian Journal of Pathology and Microbiology; 4: 761-3, 2011.

32- KALPRAVIDH R.W., SIRITANARATKUL N., INSAIN P., et al.: Improvement in oxidative stress and antioxidant parameters in 3 -thalassemia/Hb E patients treated with curcuminoids. Clin. Biochem.; 43: 424-9, 2010.

33- JOMOVA K. and VALKO M.: Importance of iron chelation in free radical-induced oxidative stress and human disease. Curr. Pharm. Des.; 17: 3460-73, 2011.

34- BOLEA I., GELLA A. and UNZETA M.: Propargylaminederived multitarget-directed ligands: Fighting Alzheimer's disease with monoamine oxidase inhibitors. Journal of Neural Transmission; 6: 893, 2013.

35- KORKMAZ S., BARNUCZ E., LOGANATHAN S., e al.: Q50, an iron-chelating and zinc-complexing agent, improves cardiac function in rat models of ischemia/ reperfusion-induced myocardial injury. Circ. J.; 77: 181726, 2013.

36- KO B.S., CHANG C.S., CHANG M.C., et al.: Guidelines for treating iron overload in myelodysplastic syndromes: A Taiwan consensus statement. Int. J. Hematol.; 100: $7-$ $15,2014$.

37- SHENOY N., VALLUMSETLA N., RACHMILEWITZ E., et al.: Impact of iron overload and potential benefit from iron chelation in low-risk myelodysplastic syndrome. Blood; 124: 873-81, 2014. 


\section{حالة الآكسلدة ومضادات الاككسدة فى مرضى الثلاسيميا العظمى-بيتا}

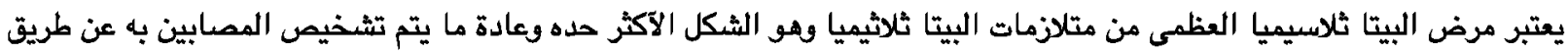

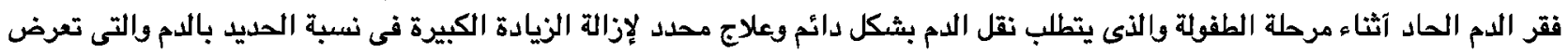

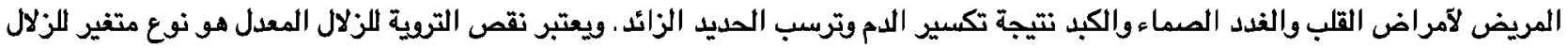

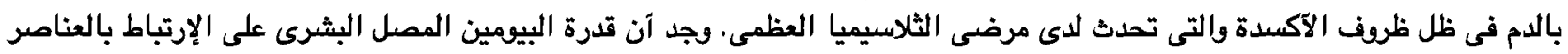

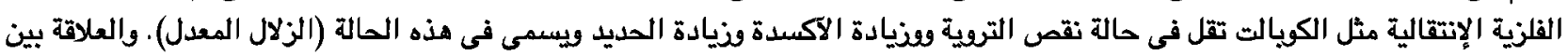

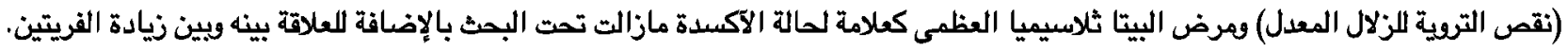

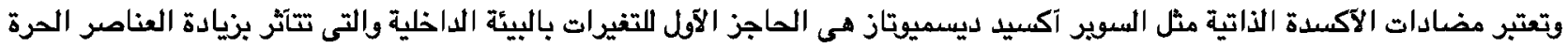

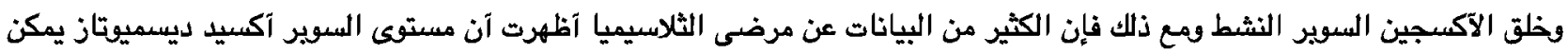
آن يختلف من مستوى منخفض (لا يختلف عن الآصحاء) ويصل إلى مستوى عالى عالى وهذا بإختيلاف العلاج.

الهدف من البحث: تهدف الدراسة إلى تقييم مستوى نقص التروية اللزلال المعدل كمؤشر للاكسدة ومستوى سوبر آكسيد ديسميوتاز كمضاد

للاكسدة فى مرضى الثلاسيميا العظمى البيتيا.

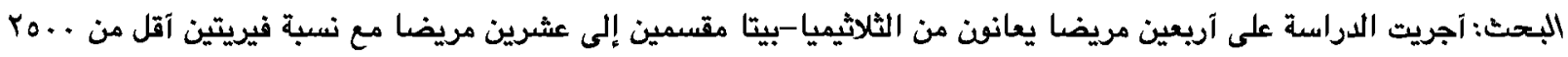

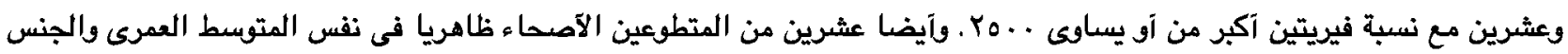

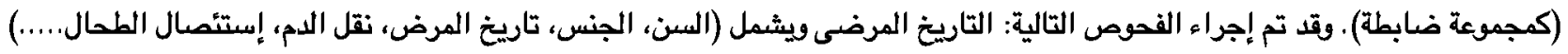

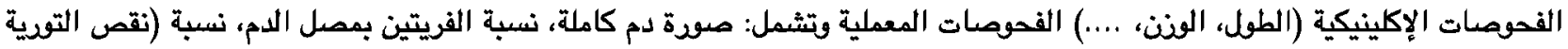

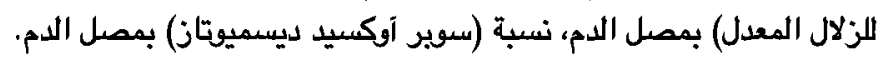

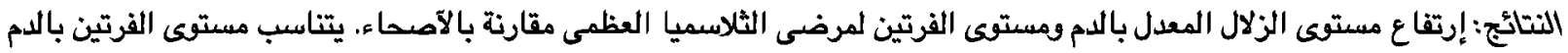

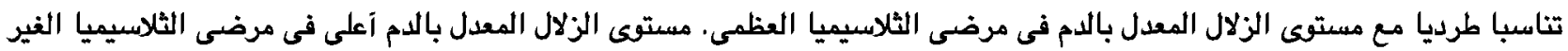

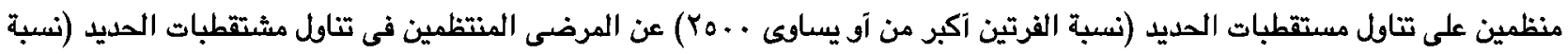

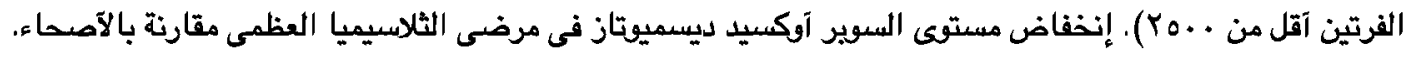
يتناسب مستوى الفريتين بالدم تناسبا عكسيا مع مستوى السوبر آوكسيد ديسميوتاز فى مرضى الثلاسيميا العظمى. مستوى السوير آوكسيد ديسميوتاز آتل فى مرضى الثلاسيميا الغير منتظمين على تناول مستقطبات العديد (نسبة الفرتين آكبر من آى آى

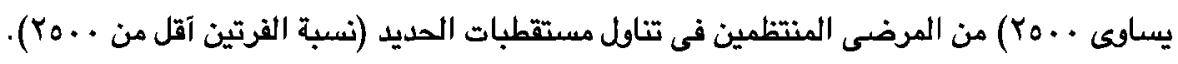

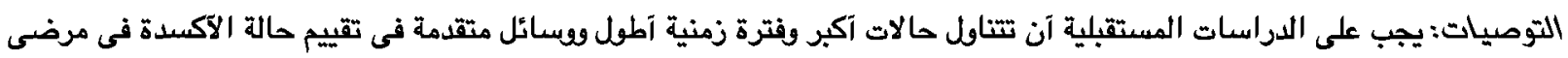

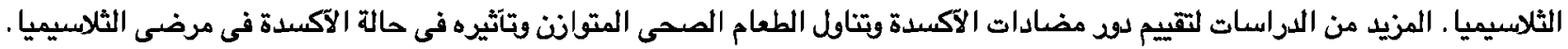

